\title{
Effect of Preoperative Nursing Protocol on Pain and Daily Activities for Post Inguinal Hernia Repair Patients
}

\author{
Eman Abdelmobdy Ali ${ }^{1}$, Islam Ibrahim Ragab ${ }^{2}$, Mohammed Abdel Shafy Mohammed ${ }^{3}$, Rokaia Fathi Mohamed ${ }^{4}$
}

(1) Clinical instructor of Medical Surgical Nursing-Faculty of Nursing - South Valley University

(2) Assistant Professor of Medical Surgical Nursing - Faculty of Nursing - South Valley University

(3) Assistant Professor of General Surgery Department- Faculty of Medicine - South Valley University

(4) Lecturer of Medical Surgical Nursing - Faculty of Nursing- Minia University

*Email of the corresponding author: eman_mobdy92@yahoo.com

\begin{abstract}
:
Background: Pain is the most serious long-term complication occurring after inguinal hernia repair with negative effects on all daily activities. As teaching is considered an important part of nursing care, interventions aimed to reduce pain and improving daily activities following surgical inguinal hernia repair are critically needed. Aim of the study: To investigate the effect of Preoperative nursing protocol on reducing pain and improving daily activities post inguinal hernia repair. Methodology: Research design: Quasi-experimental research design was utilized in the present study. Sample: A purposive sample of (60) male patients undergoing inguinal hernia repair surgery. Setting: The study was carried out at the general surgical unit of Qena University Hospital, Qena governorate, Egypt. Tools of data collection: Three tools were utilized to collect data, First Tool: Structured questionnaire covered 3 parts: First part: Demographic data of the patients. Second part: Medical profile of the patients. Third part: Included knowledge assessment sheet about inguinal hernia disease, pain-relieving strategies and, how to prevent inguinal hernia recurrence. Second Tool: Pain numerical rating scale. Third Tool: Physical self-maintenance scale (Activities of daily living). Study Duration: Data collection of this study was carried out through six months, from the beginning of December 2019 till the end of May 2020. Results: our results revealed that ages among the study and the control groups ranged between (51 to 60 years), with a mean age (51.7 \pm 9.42 years and $55.4 \pm 6.21$ years) respectively. Also, the study group demonstrated low level of pain as compared to control group after application of nursing interventions with a statistical significant difference between the mean score of pain level among the study and the control groups whereas the $1^{\text {st }}$ follow-up was $(2.03 \pm 0.66 \& 0.16 \pm 0.37)$ respectively, at the $2^{\text {nd }}$ follow-up was $(5.83 \pm 0.46 \& 3.57 \pm 0.50)$ respectively, and at the $3^{\text {rd }}$ follow-up was $(5.97 \pm 0.183 \& 5.53 \pm 0.507)$ respectively, moreover the mean score of daily living activities of the study group improved versus the control group with a statistical significant difference in which the $1^{\text {st }}$ follow-up was $(1.93+.691 \& 0.23+0.43)$ respectively, at the $2^{\text {nd }}$ follow-up was $(5.33+0.661 \& 3.6+0.563)$ respectively, and at the $3^{\text {rd }}$ follow-up was $(5.93+0.2454 \& 5.53+0.507)$ respectively. Conclusion: application of preoperative nursing protocol reflected a significant effect on patient's outcomes among the study group as postoperative pain level declined and level of activities increased as compared to the control group. Recommendations: Educational classes with a guide booklet should be provided at regular intervals for patients undergoing hernia repair, and replication of the current study on a larger probability sample from different geographical areas to achieve generalizable results are recommended.

Key Words: Preoperative, Nursing protocol, Pain, Activities of Daily Living (ADLs), Inguinal hernia.
\end{abstract}

\section{Introduction:}

Hernia occurs when a viscus or a part of a viscus is abnormally pushed out as a result of a defect either weak muscles or a tear in the wall of the cavity containing the viscus. According to the location, a hernia can be classified into inguinal, femoral, umbilical, incisional and hiatus hernia. An inguinal hernia is the most common type estimated at about $75 \%$ of all types and occurs when bowel or fatty tissue protrudes into the groin area, about $80-90 \%$ of inguinal hernias usually occur in males (Townsend, et al., 2017).

Surgical Inguinal hernia repair is the choice of treatment in most cases and is considered one of the most common surgeries performed worldwide. Annually, more than 20 million surgical inguinal hernia repairs are conducted worldwide (Kockerling and Simons, 2018). While in Egypt; surgical inguinal hernia repair was estimated at about 240000 patients in 2015 (Fawzy, et al., 2016).

Pain is the most serious long-term complication occurring after inguinal hernia repair, it was founded that more than $38 \%$ of patients suffering from moderate to severe pain for 6 months after groin hernia repair with negative consequences on all daily activities including walking,

$P$ a g e | 130 working, sleeping, personal relationships, mood and general enjoyment of life (Reinpold, 2017).

There is a strong correlation between pain and limited daily living activities (ADLs), it was founded that $30 \%$ to $50 \%$ of people with chronic pain suffered from limitations to walk, to participate in social activities and to maintain an independent lifestyle. The level of limitation affected by some factors e.g. severity, location, and duration of pain. (Duenas, et al., 2020)

Unrelieved acute postoperative pain has been found to be a contributing factor to the development of chronic pain. Therefore, interventions aimed at reducing pain following inguinal hernia surgery are critical. Pre-operative teaching provides patients undergoing surgery with information about the surgical procedure as well as information about postoperative sensations, including pain and other adverse symptoms. (Sawhney, et al., 2017).

As teaching considered an important part of nursing care, preoperatively the nurse should prepare the patient with written and verbal explanations including teach the patient pain relieving strategies such as; (breathing exercise, cold applications to reduce scrotal swelling, positioning as recumbent position or flexion of the hip and thigh, supporting 
the site, applying gentle pressure on operation site while coughing, sneezing and moving between sitting and standing, avoidance of heavy activity, and straining in toilet) as well as counseling educations about actions and life style modifications that preventing its recurrence all are considered helpful measures to relief painful symptoms (Sawhney, et al., 2017) .

\section{Significance of the study:}

Surgical inguinal hernia is considered one of the most common surgical interventions, according to the last registration records of Qena University Hospital from (January 2017 to December 2017) in which the number of inguinal hernia repair patients was (288) cases.

Related literature illustrated that pain following inguinal herniorrhaphy is most relevant and an ignored problem associated with negative consequences on a functional level and the quality of life, with incidence rates varies between $(0.7-48.3 \%)$ and high follow-up rates (Reinpold, 2017 and Fawzy, et al., 2016).

Furthermore, from the clinical experience as a supervisor for faculty of nursing students at the clinical area in Qena university hospital, the researcher found that no previous studies in our geographical area had addressed this problem, and there was a lack of assessing the functional consequences of groin pain after herniorrhaphy and effectiveness of patient education on improving the level of pain and level of activity.

\section{Aim of the study:}

The aim of the current study was to investigate the effect of a nursing protocol on reducing pain and improving daily activities post inguinal hernia repair.

\section{Research Hypotheses:}

- Patients of the study group will exhibit reduced pain level rather than patients of the control group after application of the preoperative nursing protocol.

- Patients of the study group will have improved level of daily activities than patients of the control group after application of the preoperative nursing protocol.

\section{Research Design:}

A quasi-experimental research design was utilized to fulfill the purpose of this study.

\section{Subjects:}

A purposive sample of (60) male patients undergoing inguinal hernia repair surgery.

\section{Sampling size:}

According to the following formula

(Nagy, et al., 2019):

$$
\begin{gathered}
\mathrm{N}=\frac{\mathrm{t}^{2} \times \mathrm{p}(1-\mathrm{p})}{\mathrm{m}^{2}} \\
\mathrm{~N}=\frac{(1.96)^{2} \times 0.04(1-0.04)}{0.05^{2}}
\end{gathered}
$$

- $\quad \mathrm{N}=60$ patients

\section{Inclusion criteria:}

- Adult male (21-60) years.

- Conscious and oriented.

- Patients without other causative conditions of pains (e.g. arthritis).
Exclusion criteria:

- Patients receiving long-term analgesics.

- Patients have a recurrent inguinal hernia.

The setting of the study:

This study was conducted at the general surgical unit in Qena University Hospital, Qena governorate, Egypt.

\section{Study Duration:}

Data collection for this study was carried out through six months, from the beginning of December 2019 till the end of May 2020.

\section{Tools of data collection:}

Three tools were utilized in order to fulfill this study:

\section{First Tool: Structured questionnaire sheet:}

It was used for both groups before the surgery. It consisted of two parts collected by the researcher as the following:

\section{Part (1): Demographic characteristics:}

(e.g. name, age, residence, marital status, occupation and level of education).

Part (2): Medical data profile: included (past medical and surgical history, date of admission, and date of surgery).

Part (3): knowledge assessment sheet:

It used to assess patient's knowledge about inguinal hernia (definition, potential postoperative complications, painrelieving strategies post inguinal hernia repair including \{relaxation techniques as breathing exercise and distraction also cold applications for reducing scrotal swelling and positioning like recumbent position or flexion hip and thigh adding to supporting techniques as applying gentle pressure on operation site during coughing, sneezing, and moving, finally, avoidance of heavy activity or straining , in addition, actions to prevent the recurrence of inguinal hernia after surgery).

It included (32) multiple-choice questions collected by the researcher and used pre- surgery for the control group without giving the nursing protocol while used for the study group before and after giving and explaining the nursing protocol.

\section{Scoring system:}

If patients have a score of $60 \%$ and more it was considered "satisfactory level of knowledge" and if less than a score of $60 \%$ it was considered "unsatisfactory level of knowledge" (Fawzy, et al., 2016)

\section{Second Tool: Pain numerical rating scale adopted from (McCaffery \& Beebe, 1989)}

It was applied for both groups (study and control) on the second day postoperatively, then during follow-up after one and three months by telephone. The rating scale scored as the following; from (0 to 10) (11point scale) with the understanding that $(0)$ is equal to no pain and 10 is equal to worst possible pain.

\section{Scoring system}

(Zero) score indicated absence of pain, (1-3) scores indicated mild pain, (4-6) scores indicated moderate pain, and (7-10) scores indicated severe pain. 
3. Third tool: Physical self-maintenance scale (Activities of daily living, or ADLs) Developed by (Lawton \& Brody, 1969)

It was applied on the second day postoperatively, then during follow-up after one, and three months by telephone for both groups.

Its categories are: (Toilet, feeding, dressing, grooming, physical ambulation and bathing).

\section{Scoring system:}

The total score ranges from (0 to 6), only the highest level of function receives a (1) because each describes competence that represents some minimal level of function.

Educational booklet the content of nursing protocol was developed by the researcher based on reviewing the current national and international literature to improve patient's knowledge about the disease (as a definition of the disease, risk factors, potential post-operative complications, painrelieving strategies post inguinal hernia repair, and methods of preventing its recurrence) and improve patient's performance through educated the patient how to practice pain-relieving strategies that include (Deep breathing exercise, distraction, cold application, positioning, supporting the site, avoidance of straining and heavy activities) and how to use pain numerical scale.

\section{Tools Validity:}

The tools were tested for content validity by a jury of five experts in the field of the study and necessary modifications were done. The tools were tested for internal consistency.

\section{Tools Reliability:}

It was established by the Alpha Cronbach's test which is used to measure the internal consistency (reliability of the used tool or instrument). The reliability scores of the tools are (0.95 and 0.94) for pain scale and Daily living activities scale respectively, which indicates the high tool internal consistency of the used tool.

\section{Pilot study:}

A pilot study was conducted on 6 subjects $(10 \%$ of the total sample) to ensure the clarity and utility of designed study tools and to identify any difficulties or problems that needed to be handled before receiving it. They were included in our actual sample because no modifications needed to be performed.

\section{Ethical Considerations:}

Official permission to conduct the study was obtained by the researcher from the responsible hospital authorities of the general surgical department at Qena university hospital. At the initial interview, each patient was informed of the purpose of the study. The investigator emphasized that the participation is voluntary and confidentially and anonymity of subjects will be assured through coding of all data. Confidentiality of the data was asserted. The aim of the study was explained to patients by the researcher. The right to refuse to participate in the study was emphasized to the patients. This study was approved by the research ethical committee of the faculty of nursing at Minia University.

\section{Data Collection Procedure:}

Phase I: Preparatory and administrative phase: Official letter was issued from the dean of the faculty of nursing Minia University to the head of the Qena University Hospital soliciting the necessary approval to conduct the present research and then official permission to conduct the proposed study was obtained by the researcher from the manager of Qena University Hospital.

Phase II: Implementation phase: Once the permission was obtained to conduct the study, the researcher initiated data collection. Collection of data was started from the beginning of December 2019 to the end of May 2020, through 2 days weekly during morning and afternoon shifts.

As well as official permission from the patients was granted, patients were divided into both control and study groups randomly (30 patients for each group) according to their admission to the surgical department. Those (30 patients) who admitted first constituted the control group subjects and other (30 patients) who came after constituted the study group ones.

The study and control groups were visited by the investigator to initiate line of communication, explain the nature and purpose of the study and fill out the first tool (part I, II, and III) as a pre-test. This tool was filled by the researcher within (15-30) $\mathrm{min}$.

The control group was exposed to routine nursing care, while the developed nursing protocol was applied for the study group with demonstration and return demonstration included methods to reduce pain after inguinal hernia repair, actions that prevent inguinal hernia recurrence and how to use pain numerical scale, this educational session took about 30 40 minutes, then immediate posttest was done for patients in the study group using the third part (knowledge assessment sheet) which filled by the researcher within (15-20 min) before the surgery.

Phase III: Evaluation phase: The second day postoperatively for each patient on both study and control groups, the researcher used tool II (pain numerical rating scale) and tool III (Activities of daily living scale), then during follow-up after one and three months by telephone.

\section{Limitations/difficulties of the study:}

(1) Interruptions during interviewing by staff members.

(2) Some patients were missed during the follow up (2 patients from the control group and 1 from the study group) and the researcher replaced them with other cases.

\section{Statistical Analysis of Data:}

Data entry was done using a compatible personal computer. Data entry and statistical analysis were done using SPSS 23.0 statistical software package. Data were presented using descriptive statistics in the form of frequencies and percentages for qualitative variables, means and standard deviations for quantitative variables. T-test was used to compare means. Qualitative variables categorical were comparing using chi-square or Fisher exact test as appropriate. ANOVA test and Pearson correlation were used to detect the relation between variables. Statistical significance was at pvalue $<.05$. 


\section{Results:}

Table (1): Frequency distribution of the study \& control groups according to their demographic data $(\mathrm{N}=60)$.

\begin{tabular}{|c|c|c|c|c|c|c|}
\hline \multirow[t]{2}{*}{ Demographic data } & \multicolumn{2}{|c|}{$\begin{array}{c}\text { Study group } \\
\text { N (30) }\end{array}$} & \multicolumn{2}{|c|}{$\begin{array}{c}\text { Control group } \\
\text { N (30) } \\
\end{array}$} & \multirow[t]{2}{*}{ Fisher / x 2} & \multirow[t]{2}{*}{$P$ - value } \\
\hline & (N) & $(\%)$ & $(\mathbf{N})$ & $(\%)$ & & \\
\hline \multicolumn{7}{|c|}{ (1) Age: } \\
\hline $21-30 y r s$ & 3 & 10 & 1 & 3.3 & \multirow{4}{*}{2.36} & \multirow{4}{*}{$\begin{array}{l}.469 \\
\text { (NS) }\end{array}$} \\
\hline $31-40 \mathrm{yrs}$ & 3 & 10 & 1 & 3.3 & & \\
\hline $41-50 \mathrm{yrs}$ & 9 & 30 & 9 & 30 & & \\
\hline $51-60 \mathrm{yrs}$ & 15 & 50 & 19 & 63.3 & & \\
\hline Mean+SD & \multicolumn{2}{|c|}{$51.7+9.42$} & \multicolumn{2}{|c|}{$55.4+6.21$} & 1.77 & $.081(\mathrm{NS})$ \\
\hline \multicolumn{7}{|l|}{ (2) Residence : } \\
\hline Urban & 10 & 33.3 & 9 & 30 & \multirow{2}{*}{.077} & \multirow{2}{*}{$\begin{array}{l}1.00 \\
\text { (NS) }\end{array}$} \\
\hline Rural & 20 & 73.3 & 21 & 70 & & \\
\hline \multicolumn{7}{|l|}{ (3) Marital statues: } \\
\hline Single & 7 & 23.3 & 1 & 3.3 & \multirow{3}{*}{5.35} & \multirow{3}{*}{$.052 *$} \\
\hline Married & 22 & 73.3 & 28 & 93.3 & & \\
\hline Widow & 1 & 3.3 & 1 & 3.3 & & \\
\hline \multicolumn{7}{|c|}{ (4) Occupation: } \\
\hline Manual & 14 & 46.7 & 14 & 46.7 & \multirow{3}{*}{3.11} & \multirow{3}{*}{$.192(\mathrm{NS})$} \\
\hline Office & 15 & 50 & 11 & 36.7 & & \\
\hline Other & 1 & 3.3 & 5 & 16.7 & & \\
\hline \multicolumn{7}{|l|}{ (5) Educational level: } \\
\hline Illiterate & 8 & 26.7 & 10 & 33.3 & \multirow{4}{*}{2.67} & \multirow{4}{*}{$\begin{array}{l}.485 \\
\text { (NS) }\end{array}$} \\
\hline Reads and write & 6 & 20 & 9 & 30 & & \\
\hline - ${ }_{\text {education }}$ Secondary- & 12 & 40 & 10 & 33.3 & & \\
\hline High education & 4 & 13.3 & 1 & 3.3 & & \\
\hline
\end{tabular}

$\mathbf{N S}=$ Not significant $\quad * \mathbf{p} \leq \mathbf{. 0 5}$ (statistical significance) (Chi square and fisher exact test)

Table (1): Illustrated the frequency distribution of the study and control groups according to their demographic data. It was found that their ages ranged between (51 to 60 years), with a mean age among study and control groups (51.7+9.42 years and $55.4+6.21$ years) respectively, most of them were lived in rural areas, most of them were married, while highest percentage were manual workers, and the highest percentage in the study group were secondary educated.

Table (2): Comparison between the study and the control groups according to mean score of pain level through three times of follow up. $(\mathrm{N}=\mathbf{6 0})$

\begin{tabular}{|c|c|c|c|c|}
\hline \multirow{3}{*}{ Times of follow up } & \multicolumn{4}{|c|}{ Mean score of pain level } \\
\hline & $\begin{array}{c}\text { Study group } \\
(\mathrm{N}=\mathbf{3 0})\end{array}$ & $\begin{array}{c}\text { Control group } \\
(\mathbf{N}=\mathbf{3 0})\end{array}$ & \multirow[t]{2}{*}{ T-test } & \multirow[t]{2}{*}{$\mathbf{P}$} \\
\hline & Mean +SD & Mean+ SD & & \\
\hline Pain after 2 days & $.16 \pm 0.371$ & $2.03 \pm 0.66$ & 13.3 & $.000^{* *}$ \\
\hline Pain after 1 month & $3.83 \pm 0.46$ & $5.57 \pm 0.50$ & 18.2 & $.000^{* *}$ \\
\hline Pain after 3 months & $2.97 \pm 0.183$ & $5.53 \pm 0.507$ & 4.176 & $.000^{* *}$ \\
\hline
\end{tabular}

$* \mathbf{p} \leq \mathbf{0 . 0 5}$ (significant) $\quad * * \mathbf{p} \leq .01$ (highly statistical significance)

(student T-test)

Table (2): Shows the comparison between the study and the control groups according to the mean score of pain level, through three times of follow up. It revealed that there was a significant improvement of pain level for the study group versus the control group at the three times of follow-up with highly statistically significant differences reflected by $\mathrm{P}-\mathrm{Value}(.000 * *)$.

Table (3): Comparison between the study and control groups according to mean score of daily living activities and T-test difference through the three times of follow up $(\mathrm{N}=60)$

\begin{tabular}{|c|c|c|c|c|}
\hline \multirow{3}{*}{$\begin{array}{l}\text { Times of } \\
\text { follow up }\end{array}$} & \multicolumn{4}{|c|}{ Mean score of daily living activities } \\
\hline & $\begin{array}{c}\text { Study group } \\
(\mathbf{N}=\mathbf{3 0})\end{array}$ & $\begin{array}{c}\text { Control group } \\
(\mathbf{N}=\mathbf{3 0})\end{array}$ & T-test & $\mathbf{P}$ \\
\hline & Mean +SD & Mean+ SD & & \\
\hline ADLs after 2 days & $1.93+.691$ & $0.23+0.43$ & 12.420 & $.000^{* *}$ \\
\hline ADLs after 1 month & $5.33+0.661$ & $3.6+0.563$ & 12.095 & $.000 * *$ \\
\hline ADLs after 3 months & $5.93+0.2454$ & $3.53+0.507$ & 3.890 & $.000^{* *}$ \\
\hline
\end{tabular}

$* \mathbf{p} \leq \mathbf{0 . 0 5}$ (significant) $\quad * * \mathbf{p} \leq .01$ (highly statistical significance) $\quad$ (student T-test)

Table (3): Clarifies the comparison between the study and the control groups according to mean score of daily living activities through the three times of follow up. It was found that there was a significant increase in the mean score of daily physical activities for the study group versus the control group at the three times of follow up with a highly statistical significant difference reflected by P-Value $\left(.000^{* *}\right)$. 
Table (4): Relation between demographic data and the mean score of pain level for the study and the control groups at the three times of follow-up $(\mathrm{N}=60)$

\begin{tabular}{|c|c|c|c|c|c|c|}
\hline \multirow[b]{3}{*}{ Demographic data } & \multicolumn{6}{|c|}{ Study group $(\mathrm{N}=\mathbf{3 0})$} \\
\hline & \multicolumn{2}{|c|}{$\begin{array}{l}\text { Pain after } \\
2 \text { days }\end{array}$} & \multicolumn{2}{|c|}{$\begin{array}{c}\text { Pain after } \\
1 \text { month }\end{array}$} & \multicolumn{2}{|c|}{$\begin{array}{c}\text { Pain after } \\
3 \text { months }\end{array}$} \\
\hline & $\begin{array}{l}\text { Mean } \\
\pm \text { SD }\end{array}$ & $\begin{array}{l}\text { Test of } \\
\text { Significance } \\
\text { F(P-Value) }\end{array}$ & $\begin{array}{l}\text { Mean } \\
\pm \text { SD }\end{array}$ & $\begin{array}{c}\text { Test of } \\
\text { Significanc } \\
\text { e } \\
\text { F(P-Value) } \\
\end{array}$ & $\begin{array}{l}\text { Mean } \\
\pm \text { SD }\end{array}$ & $\begin{array}{c}\text { Test of } \\
\text { Significance } \\
\text { F(P-Value })\end{array}$ \\
\hline $\begin{array}{l}\text { (1)Age :- } \\
1-30 \\
1-40 \\
1-50 \\
1-60\end{array}$ & $\begin{array}{c}5.67 \pm 1.528 \\
4.67 \pm 1.155 \\
4.11 \pm .333 \\
4.8 \pm .862\end{array}$ & $\begin{array}{l}2.813 \\
(.059)^{*}\end{array}$ & $\begin{array}{c}1.67 \pm 1.155 \\
1.67 \pm .1 .155 \\
1.33 \pm .707 \\
2.13 \pm 1.246\end{array}$ & $\begin{array}{l}1.041 \\
(.391) \mathrm{NS}\end{array}$ & $\begin{array}{c}1.00 \pm 1.0 \\
0 \\
.33 \pm .577 \\
.22 \pm .667 \\
.73 \pm .799\end{array}$ & $\begin{array}{c}1.264 \\
(.307) \mathrm{NS}\end{array}$ \\
\hline $\begin{array}{l}\text { (2) Residence:- } \\
\text { Rban } \\
\text { ural }\end{array}$ & $\begin{array}{c}5 \pm 1.054 \\
4.5 \pm .827\end{array}$ & $\begin{array}{r}2.029 \\
(.165) \mathrm{NS}\end{array}$ & $\begin{array}{c}1.9 \pm .1 .287 \\
1.75 \pm 1.020\end{array}$ & $\begin{array}{c}.121 \\
(.730) \mathrm{NS}\end{array}$ & $\begin{array}{l}.8 \pm .919 \\
.45 \pm .686\end{array}$ & $\begin{array}{l}1.382 \\
(.250) \mathrm{NS}\end{array}$ \\
\hline $\begin{array}{l}\text { (3) Marital status:- } \\
\text { Single } \\
\text { married } \\
\text { widow } \\
\end{array}$ & $\begin{array}{c}4.71 \pm \\
1.254 \\
4.59 \pm .796 \\
6 \pm .000 \\
\end{array}$ & $\begin{array}{c}1.139 \\
(.335) \mathrm{NS}\end{array}$ & $\begin{array}{c}1.57 \pm .976 \\
1.77 \pm 1.066 \\
4 \pm .000\end{array}$ & $\begin{array}{c}2.383 \\
(.111) \mathrm{NS}\end{array}$ & $\begin{array}{c}.43 \pm .787 \\
.55 \pm .739 \\
2 \pm .000\end{array}$ & $\begin{array}{c}1.956 \\
(.161) \mathrm{NS}\end{array}$ \\
\hline $\begin{array}{l}\text { (4) Occupation: } \\
\text { manual } \\
\text { office } \\
\text { other }\end{array}$ & $\begin{array}{c}4.83 \pm 0.835 \\
4.53 \pm 1.007 \\
5 \pm .000\end{array}$ & $\begin{array}{c}.432 \\
(.654) \mathrm{NS}\end{array}$ & $\begin{array}{c}2.08 \pm 1.165 \\
1.53 \pm 1.007 \\
3 \pm .000\end{array}$ & $\begin{array}{l}1.581 \\
(.224) \mathrm{NS}\end{array}$ & $\begin{array}{c}.83 \pm .835 \\
.35 \pm .702 \\
1.00 \pm .00 \\
0\end{array}$ & $\begin{array}{c}1.578 \\
(.225) \mathrm{NS}\end{array}$ \\
\hline $\begin{array}{l}\text { (5) Educational level: } \\
\text { illiterate } \\
\text { reads and write } \\
\text { secondary education } \\
\text { high education }\end{array}$ & $\begin{array}{c}5.56 \pm .726 \\
4.33 \pm .816 \\
4.18 \pm .603 \\
4.5 \pm 1.00\end{array}$ & $\begin{array}{c}6.397 \\
(.002)^{* *}\end{array}$ & $\begin{array}{c}3.00 \pm 1.00 \\
1.67 \pm .816 \\
1.018 \pm .603 \\
1 \pm .000\end{array}$ & $\begin{array}{l}11.481 \\
(.000)^{* *}\end{array}$ & $\begin{array}{c}1.33 \pm .70 \\
7 \\
.33 \pm .516 \\
.09 \pm .302 \\
.50 \pm 1.00\end{array}$ & $\begin{array}{l}7.618 \\
(.001)^{* *}\end{array}$ \\
\hline
\end{tabular}

\begin{tabular}{|c|c|c|c|c|c|c|}
\hline \multirow[b]{3}{*}{ Demographic data } & \multicolumn{6}{|c|}{ Control group $(\mathrm{N}=30)$} \\
\hline & \multicolumn{2}{|c|}{$\begin{array}{c}\text { Pain after } \\
2 \text { days }\end{array}$} & \multicolumn{2}{|c|}{$\begin{array}{c}\text { Pain after } \\
1 \text { month }\end{array}$} & \multicolumn{2}{|c|}{$\begin{array}{l}\text { Pain after } \\
3 \text { months }\end{array}$} \\
\hline & $\begin{array}{c}\text { Mean } \\
\pm \text { SD }\end{array}$ & $\begin{array}{c}\text { Test of } \\
\text { Significan } \\
\text { ce } \\
\text { F(P- } \\
\text { Value) }\end{array}$ & $\begin{array}{l}\text { Mean } \\
\pm \text { SD }\end{array}$ & $\begin{array}{c}\text { Test of } \\
\text { Significanc } \\
\text { e } \\
\text { F(P-Value) }\end{array}$ & $\begin{array}{l}\text { Mean } \\
\pm \text { SD }\end{array}$ & $\begin{array}{c}\text { Test of } \\
\text { Significan } \\
\text { ce } \\
\text { F(P- } \\
\text { Value) } \\
\end{array}$ \\
\hline $\begin{array}{l}\text { (1)Age :- } \\
1-30 \\
1-40 \\
1-50 \\
1-60\end{array}$ & $\begin{array}{c}9 \pm .000 \\
9 \pm .000 \\
7.89 \pm .601 \\
7.68 \pm .478\end{array}$ & $\begin{array}{c}3.931 \\
(.019) *\end{array}$ & $\begin{array}{c}5 \pm .000 \\
4 \pm .000 \\
4.33 \pm 1.000 \\
4.32 \pm .749\end{array}$ & $\begin{array}{c}.269 \\
(.847) \mathrm{NS}\end{array}$ & $\begin{array}{c}2 \pm .000 \\
3 \pm .000 \\
2.78 \pm .441 \\
2.63 \pm .496\end{array}$ & $\begin{array}{c}1.001 \\
(.408) \mathrm{NS}\end{array}$ \\
\hline $\begin{array}{l}\text { (2) Residence:- } \\
\text { Rban } \\
\text { ural }\end{array}$ & $\begin{array}{l}7.89 \pm .601 \\
7.81 \pm .602 \\
\end{array}$ & $\begin{array}{l}.110 \\
(.743) \mathrm{NS}\end{array}$ & $\begin{array}{l}4.56 \pm .726 \\
4.24 \pm .831 \\
\end{array}$ & $\begin{array}{c}.986 \\
(.329) \mathrm{NS}\end{array}$ & $\begin{array}{l}2.78 \pm .441 \\
2.62 \pm .498 \\
\end{array}$ & $\begin{array}{c}.683 \\
(.416) \mathrm{NS}\end{array}$ \\
\hline $\begin{array}{l}\text { (3) Marital status:- } \\
\text { Single } \\
\text { married } \\
\text { widow }\end{array}$ & $\begin{array}{c}9 \pm .000 \\
7.79 \pm .568 \\
8 \pm .000\end{array}$ & $\begin{array}{c}2.250 \\
(.125) \mathrm{NS}\end{array}$ & $\begin{array}{c}4 \pm .000 \\
4.32 \pm .819 \\
5 \pm .000\end{array}$ & $\begin{array}{c}.417 \\
(.663) \mathrm{NS}\end{array}$ & $\begin{array}{c}3 \pm .000 \\
2.64 \pm .488 \\
3 \pm .000\end{array}$ & $\begin{array}{c}.500 \\
(.612) \mathrm{NS}\end{array}$ \\
\hline $\begin{array}{l}\text { (4) Occupation: } \\
\text { manual } \\
\text { office } \\
\text { other }\end{array}$ & $\begin{array}{c}7.79 \pm 0.57 \\
9 \\
8 \pm .632 \\
7.60 \pm .548\end{array}$ & $\begin{array}{c}.861 \\
(.434) \mathrm{NS}\end{array}$ & $\begin{array}{c}4.43 \pm .852 \\
4.18 \pm .751 \\
4.4 \pm .894\end{array}$ & $\begin{array}{c}.297 \\
(.745) \mathrm{NS}\end{array}$ & $\begin{array}{c}.469 \curlyvee, \vee \backslash \pm \\
.522 \pm 5 r, \circ 2 \\
.8 \pm .447\end{array}$ & $\begin{array}{c}.597 \\
(.558) \mathrm{NS}\end{array}$ \\
\hline $\begin{array}{l}\text { (5) Educational level: } \\
\text { illiterate } \\
\text { reads and write } \\
\text { secondary education } \\
\text { high education }\end{array}$ & $\begin{array}{c}7.8 \pm .632 \\
7.67 \pm .5 \\
7.9 \pm .568 \\
9 \pm .000\end{array}$ & $\begin{array}{c}1.699 \\
(.192) \mathrm{NS}\end{array}$ & $\begin{array}{c}4.8 \pm .632 \\
4 \pm .866 \\
4.1 \pm .738 \\
5 \pm .000\end{array}$ & $\begin{array}{c}2.49 \\
(.082) \mathrm{NS}\end{array}$ & $\begin{array}{l}r, r \cdot \pm .483 \\
r, r \wedge \pm .441 \\
r, r \cdot \pm .516 \\
r .00 \pm .000\end{array}$ & $\begin{array}{c}.875 \\
(. \Sigma 7 \vee) \mathrm{NS}\end{array}$ \\
\hline
\end{tabular}

\section{$* \mathbf{p} \leq 0.05$ (Statistical significant)}

\section{(ANOVA test)}

\section{$* * \mathbf{p} \leq 0.01$ (highly significant)}

Table (4) Displays the relation between demographic data and the mean score of pain level for the study and control groups at the three times of follow-up. It was found that there was a statistical significant relation between age and the mean score of pain level at the 1st follow-up among both study and control groups, also, there was highly statistically significant relation between educational level and mean score of pain level at the three times of follow up ( 2 days, 1 month and 3 months) among the study group revealed by $\mathrm{P}-$ Value $\left(002 * *, .000^{* *}\right.$ and $\left..001^{* *}\right)$ respectively 
Minia Scientific Nursing Journal (Print - ISSN 2537-012X) (Online - ISSN 2785-9797) Vol. (8) No. (1) December 2020

Table (5): Relation between demographic data and mean score of daily living activities for the study and control groups at the three times of follow-up $(\mathrm{N}=60)$

\begin{tabular}{|c|c|c|c|c|c|c|}
\hline \multirow[b]{3}{*}{ Demographic data } & \multicolumn{6}{|c|}{ Study group $(\mathrm{N}=30)$} \\
\hline & \multicolumn{2}{|c|}{ ADLs after 2 days } & \multicolumn{2}{|c|}{ ADLs after 1 month } & \multicolumn{2}{|c|}{ ADLs after 3 months } \\
\hline & Mean \pm SD & $\begin{array}{c}\text { Test of } \\
\text { Significance } \\
\text { F(P-Value }) \\
\end{array}$ & Mean \pm SD & $\begin{array}{c}\text { Test of } \\
\text { Significance } \\
\text { F(P-Value) } \\
\end{array}$ & Mean \pm SD & $\begin{array}{c}\text { Test of } \\
\text { Significance } \\
\text { F(P-Value) } \\
\end{array}$ \\
\hline $\begin{array}{l}\text { (1)Age :- } \\
1-30 \\
1-40 \\
1-50 \\
1-60\end{array}$ & $\begin{array}{l}2.67 \pm .577 \\
2.67 \pm .577 \\
2.22 \pm .441 \\
1.47 \pm .516\end{array}$ & $\begin{array}{c}9.481 \\
(.000)^{*}\end{array}$ & $\begin{array}{c}5.67 \pm .577 \\
6 \pm .000 \\
5.56 \pm .527 \\
5 \pm .655 \\
\end{array}$ & $\begin{array}{r}3.683 \\
(.025) *\end{array}$ & $\begin{array}{c}6 \pm .000 \\
5.67 \pm .577 \\
6 \pm .000 \\
5.93 \pm .258\end{array}$ & $\begin{array}{c}1.444 \\
(.253) \mathrm{NS}\end{array}$ \\
\hline $\begin{array}{l}\text { (2) Residence:- } \\
\text { Rban } \\
\text { ural }\end{array}$ & $\begin{array}{c}1.9 \pm .738 \\
1.95 \pm .686\end{array}$ & $\begin{array}{c}.034 \\
(.856) \mathrm{NS}\end{array}$ & $\begin{array}{c}5.3 \pm .675 \\
5.35 \pm .671\end{array}$ & $\begin{array}{c}.037 \\
(.849) \mathrm{NS}\end{array}$ & $\begin{array}{c}5.9 \pm .316 \\
5.95 \pm .224\end{array}$ & $\begin{array}{l}.252 \\
(.619) \mathrm{NS}\end{array}$ \\
\hline $\begin{array}{l}\text { (3) Marital status:- } \\
\text { Single } \\
\text { married } \\
\text { widow }\end{array}$ & $\begin{array}{c}2.29 \pm .488 \\
1.86 \pm .710 \\
1 \pm .000\end{array}$ & $\begin{array}{l}2.075 \\
(.145) \mathrm{NS}\end{array}$ & $\begin{array}{l}5.17 \pm .753 \\
5.43 \pm .590 \\
4.00 \pm .000\end{array}$ & $\begin{array}{c}2.808 \\
(.078) \mathrm{NS}\end{array}$ & $\begin{array}{c}6 \pm .000 \\
5.91 \pm .288 \\
6 \pm .000\end{array}$ & $\begin{array}{c}.300 \\
(.743) \mathrm{NS}\end{array}$ \\
\hline $\begin{array}{l}\text { (4) Occupation: } \\
\text { manual } \\
\text { office } \\
\text { other }\end{array}$ & $\begin{array}{c}1.75 \pm 0.622 \\
2.12 \pm .697 \\
1 \pm .000 \\
\end{array}$ & $\begin{array}{c}2.081 \\
(.144) \mathrm{NS}\end{array}$ & $\begin{array}{c}5.08 \pm .641 \\
5.56 \pm .629 \\
5 \pm .000 \\
\end{array}$ & $\begin{array}{r}2.245 \\
(.125) \mathrm{NS}\end{array}$ & $\begin{array}{c}5.92 \pm .277 \\
5.94 \pm .250 \\
6 \pm .000 \\
\end{array}$ & $\begin{array}{r}.044 \\
(.957) \mathrm{NS}\end{array}$ \\
\hline $\begin{array}{l}\text { (5) Educational level: } \\
\text { illiterate } \\
\text { reads and write } \\
\text { secondary education } \\
\text { high education }\end{array}$ & $\begin{array}{c}1.33 \pm .500 \\
1.83 \pm .408 \\
2.09 \pm .539 \\
3 \pm .000\end{array}$ & $\begin{array}{c}12.261 \\
(.000)^{* *}\end{array}$ & $\begin{array}{c}5 \pm .707 \\
5 \pm .632 \\
5.55 \pm .522 \\
6 \pm .000\end{array}$ & $\begin{array}{c}3.912 \\
(.020)^{* *}\end{array}$ & $\begin{array}{c}5.89 \pm .333 \\
6 \pm .000 \\
5.91 \pm .302 \\
6 \pm .000\end{array}$ & $\begin{array}{c}.331 \\
(.803) \mathrm{NS}\end{array}$ \\
\hline
\end{tabular}

\begin{tabular}{|c|c|c|c|c|c|c|}
\hline \multirow[b]{3}{*}{ Demographic data } & \multicolumn{6}{|c|}{ Control group $(\mathrm{N}=30)$} \\
\hline & \multicolumn{2}{|c|}{ ADLs after 2 days } & \multicolumn{2}{|c|}{ ADLs after 1 month } & \multicolumn{2}{|c|}{ ADLs after 3 months } \\
\hline & Mean \pm SD & $\begin{array}{c}\text { Test of } \\
\text { Significance } \\
\text { F(P-Value) } \\
\end{array}$ & Mean \pm SD & $\begin{array}{c}\text { Test of } \\
\text { Significance } \\
\text { F(P-Value) } \\
\end{array}$ & Mean \pm SD & $\begin{array}{c}\text { Test of } \\
\text { Significance } \\
\text { F(P-Value }) \\
\end{array}$ \\
\hline $\begin{array}{l}\text { (1)Age :- } \\
1-30 \\
1-40 \\
1-50 \\
1-60\end{array}$ & $\begin{array}{l}1 \pm .000 \\
1 \pm .000 \\
.44 \pm .527 \\
.05 \pm .229 \\
\end{array}$ & $\begin{array}{c}6.008 \\
(.003) * *\end{array}$ & $\begin{array}{c}4 \pm .000 \\
4 \pm .000 \\
3.89 \pm .333 \\
3.37 \pm .496 \\
\end{array}$ & $\begin{array}{c}3.357 \\
(.034) *\end{array}$ & $\begin{array}{c}4 \pm .000 \\
4 \pm .000 \\
4 \pm .500 \\
3.37 \pm .496 \\
\end{array}$ & $\begin{array}{c}3.751 \\
(.023) *\end{array}$ \\
\hline $\begin{array}{l}\text { (2) Residence:- } \\
\text { Rban } \\
\text { ural }\end{array}$ & $\begin{array}{r}.33 \pm .500 \\
.19 \pm .402\end{array}$ & $\begin{array}{c}.687 \\
(.414) \mathrm{NS}\end{array}$ & $\begin{array}{l}3.44 \pm .527 \\
3.62 \pm .498\end{array}$ & $\begin{array}{c}.750 \\
(.394) \mathrm{NS}\end{array}$ & $\begin{array}{l}3.33 \pm .500 \\
3.71 \pm .561\end{array}$ & $\begin{array}{c}3.090 \\
(.090) \mathrm{NS}\end{array}$ \\
\hline $\begin{array}{l}\text { (3) Marital status:- } \\
\text { Single } \\
\text { married } \\
\text { widow }\end{array}$ & $\begin{array}{c}1 \pm .000 \\
.21 \pm .418 \\
0 \pm .000\end{array}$ & $\begin{array}{c}1.868 \\
(.174) \mathrm{NS}\end{array}$ & $\begin{array}{c}4 \pm .000 \\
3.57 \pm .504 \\
3 \pm .000\end{array}$ & $\begin{array}{c}1.003 \\
(.380) \mathrm{NS}\end{array}$ & $\begin{array}{c}4 \pm .000 \\
3.61 \pm .567 \\
3 \pm .000\end{array}$ & $\begin{array}{c}.811 \\
(.455) \mathrm{NS}\end{array}$ \\
\hline $\begin{array}{l}\text { (4) Occupation: } \\
\text { manual } \\
\text { office } \\
\text { other }\end{array}$ & $\begin{array}{l}.14 \pm 0.363 \\
.36 \pm .505 \\
.20 \pm .474 \\
\end{array}$ & $\begin{array}{r}.819 \\
(.452) \mathrm{NS}\end{array}$ & $\begin{array}{c}3.64 \pm .497 \\
3.55 \pm .522 \\
3.4 \pm .548 \\
\end{array}$ & $\begin{array}{r}.426 \\
(.658) \mathrm{NS}\end{array}$ & $\begin{array}{l}.514 \pm 3.57 \\
.674 \pm 3.64 \\
3.60 \pm .548 \\
\end{array}$ & $\begin{array}{c}.038 \\
(.963) \mathrm{NS}\end{array}$ \\
\hline $\begin{array}{l}\text { (5) Educational level: } \\
\text { illiterate } \\
\text { reads and write } \\
\text { secondary education } \\
\text { high education }\end{array}$ & $\begin{array}{l}.20 \pm .422 \\
.11 \pm .333 \\
.30 \pm .483 \\
1 \pm .000 \\
\end{array}$ & $\begin{array}{c}1.469 \\
(.246) \mathrm{NS}\end{array}$ & $\begin{array}{c}3.5 \pm .527 \\
3.67 \pm .5 \\
3.5 \pm .527 \\
4 \pm .000 \\
\end{array}$ & $\begin{array}{r}.454 \\
(.717) \mathrm{NS}\end{array}$ & $\begin{array}{l}r . \varepsilon \pm .017 \\
r, v \wedge \pm . \varepsilon \leqslant 1 \\
r, \tau . \pm .799 \\
\varepsilon \pm .000\end{array}$ & $\frac{. \wedge \vee 7}{(.466){ }^{N S}}$ \\
\hline
\end{tabular}

$* \mathbf{p} \leq 0.05$ (Statistical significant)

(ANOVA test)

Table (5): Illustrates the relation between demographic data and mean score of daily living activities for the study and control groups at the three times of follow-up. It was found that that there was a statistical significant relation between age and the mean score of daily living activities at the three times of follow-up among both groups. Also, there was a significant relation between educational level and mean score of daily living activities at 1st and 2nd times of follow-up among the study group 
Table (6): Correlation between pain level score and daily living activities score among the study group ( $\mathrm{N}=30)$.

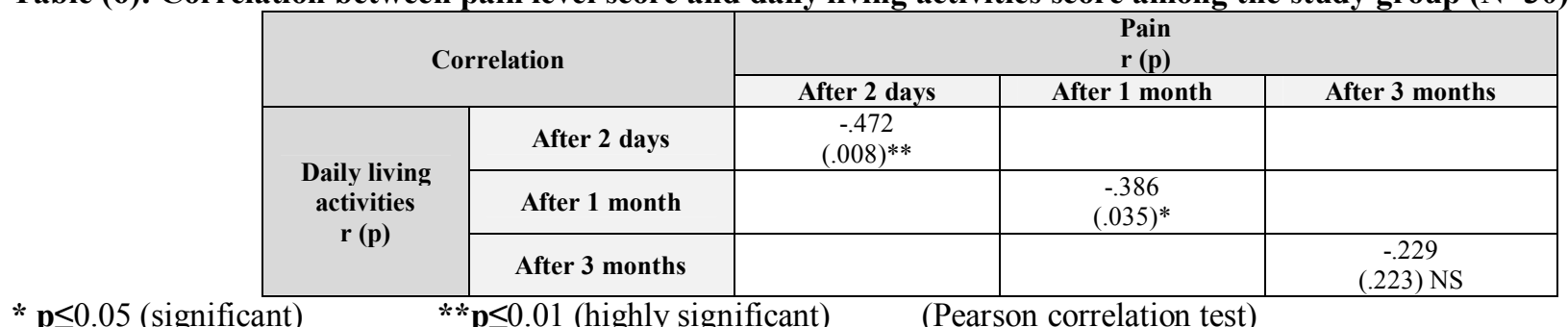

Table (6): Shows the correlation between pain level score and daily living activities score among the study. It reflects that there was a negative correlation between pain level score and daily living activities score at the three times of follow-up, with statistical significance at $1^{\text {st }}$ follow-up $(.008)^{* *}$ and $2^{\text {nd }}$ follow-up $(.035)^{*}$.

\section{Discussion:}

An inguinal hernia occurs when bowel or fatty tissue protrudes into the groin area. It is the most common type of hernias estimated at about $75 \%$ of all types. Nursing plays an important role preoperatively by providing teaching which helping patients on faster recovery and reducing complications as possible that may occur after surgery. Therefore, this research was conducted to investigate the effect of a nursing protocol on reducing pain and improving daily activities post inguinal hernia repair

\section{Discussion of the demographic characteristics of the studied sample:}

The present study revealed that more than half of the sample their ages ranged between (51 to 60 years), with a mean age among study and control groups (51.7 \pm 9.42 years and $55.4 \pm 6.21$ years) respectively. This explained as; with aging, there is a degradation induced of the elastic fibers in the deep inguinal ring. This result was supported by the study of (Sawhney, et al., 2017) who reported that the ages of the studied groups were between (50 to 60 years). Also, further validation by (Ainapure \& Singaraddi, 2018) who revealed that the majority of patients undergoing inguinal hernia repair their mean age (49.1 years).

As regard residence, it was found that most of the study and control groups were lived in rural areas. This may be attributed to the main profession of rural population is agriculture which required heavy work leading. That result was in the same line with (Fawzy, et al., 2016) which reported that the majority of both study and control groups were from the rural areas.

Concerning marital status, most of both groups were married. This result was in agreement with (Fawzy, et al., 2016), who demonstrated in her study that the married patients were more than three-quarters of the total studied sample.

As regard occupation, half of the patients in the study group were manual workers, while the highest percentage in control group was manual workers also. This fact can be explained by repeated lifting heavy materials for a long period or activities requiring high efforts, suddenly increased intraabdominal pressure leading to a higher risk of inguinal hernia incidence. This finding was supported by (Oberg, et al., 2017) which revealed that works required cumulative continual heavy lifting activities and elongated standing or walking, increased risk of inguinal hernia.

(Mitura, et al., 2018) revealed that more than half of inguinal hernia patients of the studied sample were high school educated. This agrees with our results which reported that secondary education had the highest percentage in the study group.
2. Discussion of the comparisons between the study and control groups according to the mean score of pain level and mean score of daily living activities after application of the nursing interventions:

As regards the comparison between the study and control groups according to the mean score of pain level at the three times of follow-up, our results revealed that the study group demonstrated a low level of pain as compared to the control group after application of nursing interventions with a highly statistically significant difference revealed by P-Value $\left(.000^{* *}\right)$ at the three times of follow up. These findings were in accordance with a study carried out in Canada by (Sawhney, et al., 2017) who demonstrated that pain intensity and its interference with general activity after hernia repair was found to be decreased by providing education interventions. Also, these results were in the same line with (Vaan Dijk, et al., 2015) which showed that the intervention group had higher knowledge scores and lower pain scores compared with the control group.

Concerning the comparison between the study and control groups according to the mean score of daily living activities at the three times of follow-up, results displayed that the mean score of daily living activities of the study group was improved at the three times of follow-up versus the control group with highly statistical significant differences revealed by P-Value $\left(.000^{* *}, .000^{* *} \& .001^{* *}\right)$ at the three times of follow-up respectively. The study results agreed with (Rolving, et al., 2016) who showed an important finding of his study which was the mobility of the study group and the performance of activities were better than the control group and low analgesics were needed. (Zhang, et al., 2019) health education improved the daily living activities (ADLs) of patients and improved their quality of life (QoL). Another validation by (Abdel Rahman, et al., 2017) showed that there was a significant positive correlation between total patients' knowledge and postoperative total quality of recovery. On other hand; (Sawhney, et al., 2017) evaluated the effectiveness of an individualized Hernia Repair Education Intervention (HREI) for patients following inguinal hernia repair and founded that the HREI improved patients' outcomes following ambulatory inguinal hernia repair.

3. Discussion of relationships between demographic data and mean score of pain level and mean score of daily living activities for both groups after nursing intervention:

As regard relation between demographic data and mean score of pain at the three times of follow up among the study and control groups, the results clarified that there was a statistical significant relation between age and $1^{\text {st }}$ follow-up 
among both study and control groups, as patients between (2530) age group had higher mean score of pain. Explanations for the increases in pain sensitivity under different experimental conditions have been suggested to include age-related anatomical, physiological, and biochemical changes as well as compensatory changes in homeostatic mechanisms and intrinsic plasticity of somatosensory pathways involved in the processing and perception of pain. Other potential contributing factors related to the impact of age on pain sensitivity include dysregulation of the hypothalamicpituitary-axis and changes in autonomic function along with an increased prevalence of auto-immune disorders that occur with advancing age. This finding was in agreement with (Reddy \& Srinivas, 2016) found in the study titled " Study of postoperative pain in patients with inguinal hernioplasty" who showed that there was a significant relation between the patient's age and pain, as the severity of pain decreased with age advanced. (Mitura, et al., 2018) revealed that younger patients' pain experience and its intensity were significantly higher than in the middle-aged and the oldest group. Another study for (Donati, et al., 2013) was in the same line, who demonstrated that there was no statistical significance in the difference between (younger and older patients) except for early postoperative pain. But, these results were in disagreement with (Erdogan \& Ozenc, 2018) who mentioned that their study showed there was no significant correlation between age and postoperative pain however some studies showed that as the age increased, the need for analgesia and risk of chronic pain decreased.

Regarding the relation between the educational level and the mean score of pain, there was a highly significant relation between educational level and mean score of pain at the three times of follow-up among the patients of the study group revealed by P-Value $(.002 * *, .000 * *$, and $.001 * *)$ respectively. Illiterate patients had a higher mean score of pain. This may be related to the lower mean score of knowledge for illiterate patients. These results returned to the relationship between educational level and post knowledge among study group patients and accordingly improving pain level of the patients. This result agreed with (Wong \& Yu, 2016) who found that a great improvement in the knowledge obtained by patients who have a high level of education after the implementation of an educational program. Other supplementation by (Sawhney, et al., 2017) who demonstrated that pain intensity and its interference with general activities was found to be decreased effectively after hernia repair education intervention (HREI).

Concerning to relation between the demographic data and the mean score of daily living activities at the three times of follow-up among the study and control groups, the results clarified that there was a statistical significant relation between age and the mean score of daily living activities at the three times of follow-up among both groups, as the younger age had a higher mean score, this may be due to that age leading to a deterioration of all physical activities and general health. Also, there was a significant relation between educational level and mean score of activities of daily living at $\left(1^{\text {st }}\right.$ and $2^{\text {nd }}$ follow-up) among study group patients as the highly educated patients had the higher mean score. This result agreed with (Abdel Rahman, et al., 2017) who clarified that there was a negative correlation between patients' age and physical activities.
4. Discussion of correlation between pain level score and daily living activities score for the study group:

As regard correlation between pain level score and daily living activities score at the three times of follow-up among the study group, the results displayed that there was a negative correlation between pain level score and daily living activities score at the three times of follow-up with statistical significance at 1st follow-up (.008)**, and 2nd follow-up ( $.035)^{*}$. This may be due to the bad feeling of pain with or without movement which leading to decreased ability and desire to do daily activities normally. This result was in the same line with (Altug, et al., 2017) who revealed that there were positive correlations between pain intensity and its interference with daily activities; similarly, negative correlations were found between the pain threshold and these activities.

\section{Conclusion:}

Preoperative application of preoperative nursing protocol reflected a significant effect on patients' outcomes among the study group as postoperative pain level declined and level of activities increased compared to the control group and this achieved the research hypothesis.

\section{Recommendations:}

Based on the results of the present study it can be recommended that:

\section{Recommendations for nurses:}

- Application of this preoperative nursing protocol for nurses in order to improve the quality of provided nursing care and to be able to provide sufficient education for patients undergoing inguinal hernia.

\section{Recommendations for Patients:}

- Planning educational classes supported with a guide booklet should be provided at regular intervals for patients undergoing hernia repair about methods to reduce pain, improve activity, and prevent inguinal hernia recurrence post-inguinal hernia repair.

- Written Arabic booklets or brochure and posters including post inguinal hernia repair instructions should be available at health care settings and given to patients and their caregivers.

\section{Recommendations for further researches:}

- Replication of the current study on a larger probability sample from different geographical areas to achieve generalizable results.

\section{References:}

(1) Abd El Rahman, A. A., Mahdy, N. E., \& Kamaly, A. M., (2017) Predictive factors affecting the postoperative quality of recovery for patients undergoing surgery. Journal of Nursing and health science (IOSR - JNHS), 6 (3), Pp 50-60.

(2) Ainapure R. \& Singaraddi R., (2018). Clinical study of pain after inguinal hernia repair. International surgery journal, 5(3):987-990.

(3) Altug F., Unal A., Kilavuz G., Kavlak E., Citisli V. \& Cavlak U., (2017). Investigation of the relationship between kinesiophobia, physical activity level and quality of life in patients with chronic low back pain. Journal of Back and Musculoskeletal Rehabilitation, 29, 527-531

(4) Donati M., Brancato G., Giglio A., Biondi A., Basile F., \& Donati A., (2013). Incidence of pain after inguinal hernia repair in the elderly. A retrospective historical cohort evaluation of 18-years' experience with a mesh \& plug inguinal hernia repair method on 
about 3000 patients. (BMC) BioMed Central Surgery, 13(Suppl 2):S19.

(5) Duenas M., Salazar A., Sola H. \& Failde I., (2020). Limitations in Activities of Daily Living in People With Chronic Pain: Identification of Groups Using Clusters Analysis. Pain practice; 20(2): 179-187.

(6) Erdogan E., \& Ozenc E., (2018). Factors associated with acute and chronic pain after inguinal herniorrhaphy. Romanian Journal of Anaesthesia and Intensive Care, 25(1): 31-35.

(7) Fawzy H. T., Ghanem H. M., Mohammed M. B. \& Abd Almageed A. S., (2016). Effect of designed nursing guidelines on outcomes of patients undergoing inguinal hernia repair, submitted For Partial Fulfillment of Master Degree in Adult Nursing (Medical Surgical Nursing), Faculty of Nursing, Assuit University.

(8) Kockerling F. \& Simons M. P., (2018). Current Concepts of Inguinal Hernia Repair. Visc Med; 34 (2):145-150.

(9) Lawton M.P. \& Brody E.M., (1969). Assessment of older people: self-maintaining and instrumental activities of daily living. Gerontological Society of America, 9:179-186.

(10) McCaffery, M., \& Beebe, A., (1989). Pain: Clinical manual for nursing practice, Mosby St. Louis, MO.

(11) Mitura K., Smietanski M., Kozieł S., Garnysz K. \& Michałek I., (2018). Factors influencing inguinal hernia symptoms and preoperative evaluation of symptoms by patients: results of a prospective study including 1647 patients. Hernia, 22:585-591.

(12) Nagy E. A. M., Abdelrazik A. M., Shawkat A. M. \& Fathy R. M. (2019). The Effect of Cataract Surgery Discharge Instructions on Reducing Eye Infection Post Cataract Surgery for Elderly Patients, submitted For Partial Fulfillment of Master Degree in Medical Surgical Nursing (Gerontological Nursing), Faculty of Nursing, Minia University.
(13) Oberg S., Andresen K. \& Rosenberg J., (2017). Etiology of Inguinal Hernias: A Comprehensive Review. Front Surg; 4: 52.

(14) Reddy B. \& Srinivas B. (2016). Study of post-operative pain incidence in patients with inguinal hernioplast. International Archives of Integrated Medicine IAIM, 3(10): 268-271.

(15) Reinpold W. (2017). Risk factors of chronic pain after inguinal hernia repair: a systematic review. Innov Surg Sci; 2(2): 61-68.

(16) Rolving N., Nielsen C. V., Christensen F. B., Holm R., Bunger C. E. \& Oestergaard L. G., (2016). Preoperative cognitive-behavioral intervention improves in-hospital mobilization and analgesic use for lumbar spinal fusion patients. BMC musculoskeletal disorders, 17:217.

(17) Sawhney M., Watt-watson J. \& Gillion M., (2017). Pain education intervention for patients undergoing ambulatory inguinal hernia repair: A randomized controlled trial. Canadian journal of nursing research, 49(3):108-117.

(18) Townsend C., Beauchamp D., Evers M., \& Mattox K. (2017). Sabiston textbook of surgery the biological basis of modern surgical practice.20th ed. Philadelphia. Elsevier. Chapter 44. Pp1092-1098.

(19) Van Dijk J. F., Van Wijck A. J., Peelen L. M. \& Schuurmans M. J., (2015). The Effect of a Preoperative Educational Film on Patients' Postoperative Pain in Relation to their Request for Opioids. Pain Management Nursing, 16(2): pp 137-145.

(20) Wong C. \& Yu W. (2016): Correlates of disease-specific knowledge in Chinese patients with COPD. Int $\mathbf{J}$ Chron Obstruct Pulmon Dis, 26(11): 2221-2227.

(21) Zhang X., Liu L. \& Wang L., (2019). Improvement in quality of life and activities of daily living in patients with liver cirrhosis with the use of health education and patient health empowerment. Med Sci Monti, 25:4602-4608 